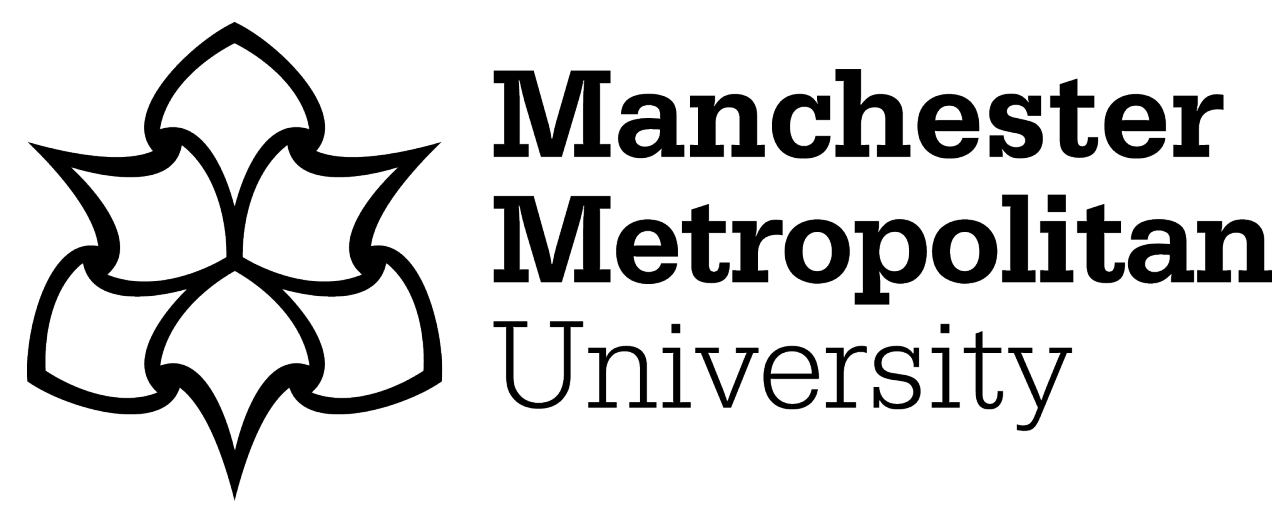

Ainsworth, Stephanie and Bell, Huw ORCID logoORCID: https://orcid.org/0000-0002-9695-9632 (2020) Affective knowledge versus affective pedagogy: the case of native grammar learning. Cambridge Journal of Education, 50 (5). pp. 597-614. ISSN 0305-764X

Downloaded from: https://e-space.mmu.ac.uk/625455/

Version: Accepted Version

Publisher: Taylor \& Francis (Routledge)

DOI: https://doi.org/10.1080/0305764X.2020.1751072

Please cite the published version 


\title{
Affective knowledge versus affective pedagogy: the case of native grammar learning
}

\section{Dr Steph Ainsworth ${ }^{1}$ and Dr Huw Bell ${ }^{1}$}

${ }^{1}$ Education and Social Research Institute, Manchester Metropolitan University

Corresponding author: Dr Steph Ainsworth, Education and Social Research Institute, Manchester Metropolitan University, 53 Bonsall Street, Manchester, UK, M15 6GX.

Email: s.ainsworth@mmu.ac.uk

\begin{abstract}
In recent years, there has been a growing interest in the role of affect within education.

Within this paper, we make a distinction between affective pedagogy, which we refer to as ways of teaching that are designed to evoke particular emotional states, and affective knowledge, which we refer to as aspects of knowledge or knowing which seem to bring forth particular emotions organically. Using explicit grammar knowledge as a test case, we explore student teachers' affective responses to learning, drawing upon interview data and observations made during a series of grammar courses. We argue that grammar learning is a potential source of pleasure, wonder and intensity. The findings provide an important counter-narrative to the prevailing discourse of grammar as dull and threatening. We also draw broader conclusions about the significance of affect in education, drawing upon affect theory and recent work on epistemic emotions.
\end{abstract}

Keywords: affect, grammar, wonder, epistemic emotions

\section{Introduction}

\section{Grammar as a contested subject}

While recent curriculum changes have led to a resurgence of explicit grammar instruction within Anglophone countries, teachers and researchers remain divided about if and how 
grammar terminology should be taught to children (Wyse \& Torgeson, 2017). Much of the debate focuses on whether or not explicit grammar teaching improves children's writing, with supporters suggesting that explicit grammar knowledge gives us 'more conscious control and choice in our language' (Department for Education, 2013a, p. 64). On the other hand, there are concerns within the UK that explicit grammar knowledge might be too abstract for young children to cope with (Rosen, 2018) and that too much emphasis on structural aspects of writing might be at the expense of creativity and pupil motivation (Wyse \& Torgeson, 2017).

This scepticism towards the teaching of explicit grammar knowledge is shared by many teachers both in training and in post (Safford, 2016). Among UK secondary English teachers, Watson found 'a dominant discourse of grammar as threatening, reactionary and dull' (2012, p. 22). In Australia, attitudes towards explicit language teaching appear to be more positive than in the UK; however, genre based knowledge is viewed as more important than sentence level knowledge (Love et al., 2015). Negative attitudes towards grammar among teachers are not, however, universal. Watson reports positive attitudes among a 'significant minority' of English teachers who view grammar as 'inspiring, fascinating and empowering' (2012, p. 22). Similarly, Bell (2016) found that primary teachers were generally supportive of the presence of grammar terminology within the curriculum, but they demonstrated a lack of confidence in relation to grammar knowledge alongside a fear of exposure.

It seems apparent, therefore, that teachers' attitudes towards the explicit teaching of grammar knowledge vary. The fact that the balance seems to be tilted towards aversion, at least within the UK, is of concern given that negative attitudes towards teaching grammar are associated with a reduced willingness and ability to teach grammar effectively (Watson, 2012). Aarts (2018) argues that one way to foster positive attitudes towards grammar in teachers is to persuade them that grammar 'enriches your life' (Aarts, 2018: online), aside from any claims that it may be useful in enhancing children's writing. Aarts acknowledges that explicit 
grammar knowledge is definitely not necessary for children to become accomplished writers, but argues that this does not mean that it should not be taught; if we are to convince teachers of the value of grammar, we need to move away from the prevalent instrumental discourse around its potential to improve writing standards and explore instead the value that grammar has as a subject in its own right (ibid).

Within the current paper, we respond to Aarts' challenge by sidestepping the question of whether grammar teaching improves writing, focussing instead on student teachers' affective responses to grammar learning. We will argue that grammar has an affective charge, which can make it both terrifying and exhilarating to learn. This provides an important counternarrative to the predominantly negative discourse around explicit grammar teaching, with important implications for both teacher education and the wider debate around the presence of grammar terminology within Anglophone curricula.

\section{Affective pedagogy versus affective knowledge}

The recent growth in interest in the role of affect within educational contexts (e.g. Niccolini et al., 2018) is part of a much broader paradigmatic shift within the humanities and the social sciences, often referred to as the affective turn (Clough, 2007), which foregrounds the importance of the body and affective experience. Alongside this philosophically rooted drive to acknowledge the centrality and potentiality of the body as an inherent part of the learning process, there are pragmatic concerns amongst educationalists and psychologists around how to maximise affective engagement within contemporary classrooms (e.g. Williamson, 2016). This move towards the development of psychopedagogies, which seek to maximise children's emotional states in order to improve performance, has been criticised as positioning children as 'psychologically susceptible', 'emotionally irrational' and 'socially manipulable' objects 
as part of a broader biopolitical agenda (ibid, p. 414). Within this paper we do not seek to explore how we might manipulate students' emotions to maximise engagement; rather we explore the inherently affective force of particular subjects, and the potentialities which these might bring to the learner as agent rather than object. We are therefore making a distinction between affective pedagogy, which we refer to here as ways of teaching that are designed to evoke particular emotional states, and affective knowledge, which refers to aspects of knowledge or knowing which seem to bring forth particular emotions organically.

Recent work has differentiated between achievement emotions (Pekrun \& Perry, 2014), which occur in response to completion of a learning task, and epistemic emotions (Muis et al., 2015), which emerge in response to the generation of knowledge. For example, while a sense of pride might arise from the satisfaction at completing a task, a sense of surprise, curiosity or confusion might result from learning something unexpected. This distinction between achievement and epistemic emotions might be usefully applied when attempting to separate affective characteristics of the learning environment versus affective characteristics of the subject itself. Within this study we consider student teachers' epistemic responses to learning grammar which seem to be driven by the process of knowing rather than from the satisfaction of completing particular tasks and challenges.

It is important to note that the term 'affect' is used in different ways by different authors and within different disciplines. While affect is often used more or less interchangeably with 'emotion' (e.g., Ahmed, 2014), many scholars have argued that there is an important distinction between the two concepts (e.g., Clough, 2007). Within the current paper, our use of affect refers to Massumi's (2002) notion (itself following Deleuze and Guattari (1988)) which is conceptualised as a pre-conscious, pre-personal, pre-linguistic intensity that affects and connects bodies. Emotion, by contrast is considered to be a secondary representation of affect within the individual: 'the sociolinguistic fixing of the quality of an experience which 
is from that point onward defined as personal' (Massumi, 2002, p. 28). From a Deleuzian perspective 'bodies' are defined as ever-changing assemblages of human and non-human elements which are in continuous relation with one another. Zembylas (2007) describes three kinds of assemblage which bodies might engage in within educational contexts:

...the cultural one of the meanings of learning/teaching within a particular space-time context, the gender assemblage that assigns meaning to bodies and learning/teaching, the emotional one that constantly cross- and inter-connects students' and teachers' emotional responses to various events and activities (p. 32).

Within the current study we explore a different kind of assemblage which connects the subject (in this case, grammar) and the learner. We explore the pockets of intensity that were generated as our students interacted with the subject and the potentialities that these intensities seemed to create. We also explore the extent to which these affective intensities were captured as epistemic emotions such as wonder.

\section{Grammar as affectively charged}

We will argue that native grammar carries a strong affective charge, drawing upon our experiences of teaching explicit grammar knowledge to student teachers over a two-year period. Our interest in the affective aspects of learning grammar was borne out of our attempts to support student teachers in developing their explicit knowledge of grammar (which tends to be initially very limited) up to the levels required by the National Curriculum in England. When teaching, we were struck by students' affective responses to learning grammar: both positive and negative. We observed that while attitudes to grammar seemed to be predominantly negative at the beginning of the course, many of our students reported changing their minds about grammar by the end, to the point where they were keen to spread the word to others. The remainder of this paper seeks to explore possible reasons for this 
apparent shift in attitudes and the meanings that the student teachers attribute to their experiences of learning grammar. Our work provides empirical support for Aarts' (2018) claim that grammar has the potential to be much more than a tool to improve writing and attempts to develop current conceptualisations around the nature and value of grammar knowledge. It also makes important observations about the role of affect in learning more generally.

\section{Method}

The study adopts an exploratory qualitative approach to the investigation of student teachers' affective responses to learning grammar. The main body of the data comes from a series of seven semi-structured group interviews with student teachers who attended a series of optional grammar sessions (groups of one to ten within each interview; a total sample of 29 student teachers). The optional grammar sessions were offered to all students within a particular cohort of the BA in Primary Education. All students who had been invited to attend the optional grammar sessions were invited to participate in a group interview where they would be asked to discuss their experiences of learning and teaching grammar. The interviews took place at three time points, following three different incarnations of the grammar course. The number of people who were invited to the sessions (and to interview), who came to the sessions and who came to the interviews within each cohort are provided in Table 1.

Each time we ran the course, we adapted it in an attempt to make it more beneficial and enjoyable for students, using our own reflections on how the sessions went (recorded as field notes) as well as feedback from the interviews to inform our teaching. Details of how the course changed from one cohort to the next are also included in Table 1. Almost all of the 
student teachers who attended the group interviews had also attended at least some of the grammar sessions. Just two participants had not attended the sessions, but had been exploring the grammar materials from the sessions online. When students were asked why they had opted to attend the grammar course, almost all of them said that it was because they wanted to feel more confident about teaching grammar in school. Further details of the content and design of the courses are described in an earlier paper, which explores issues of pedagogy in relation to grammar (Bell \& Ainsworth, 2019).

The interview questions were initially very broad, allowing students to talk about the things that felt most pertinent to them about their experiences of learning grammar. As the project progressed and we were struck by the strong affective component, both within the sessions and the interviews, we began to narrow the focus of the interviews to explore this dimension in further depth. Field notes were also made throughout each iteration of the course, to help capture impressions of the students' and our own affective responses to the sessions. Each short course consisted of 5-8 sessions of two hours each and attracted numbers of 13-50 student teachers (a total of 80 attendees).

Following transcription, the interview data and field notes were used to help us explore the following questions:

- What are the specific satisfactions of learning grammar?

- What can we learn about the role of affect in learning more generally?

Because the three groups of student teachers attending the different iterations of the course experienced variations in the learning experiences they received, it would be unwise to consider them as a homogeneous cohort of participants; it is likely that the diversity of experiences will have contributed to the student teachers' affective responses to grammar in different ways. Within this study, we do not attempt to either 'flatten' the variation in student 
teachers' responses or consider differences across the three groups. Instead we draw out themes from across the three groups which relate students' individual affective responses to the particular aspects of the subject or the learning context which the students' themselves identify as being particularly salient. It is acknowledged that not all student teachers will have encountered the same experiences, and where experiences were shared, they will not all have had the same reaction. The purpose of the analysis is not to make generalisations across student teachers but to capture and explore the moments of intensity which both surprised and excited both us and them, with a view to harnessing the potentiality for such moments within teaching more generally.

\section{Analysis}

Our analysis was necessarily inductive in nature, given that the affective dimension of learning explicit grammar knowledge is understudied, and there are consequently insufficient grounds for the development of predetermined hypotheses. We began by extracting key themes relating to student teachers' experiences of learning grammar. We then went on to explore the connections between the emerging categories (Braun and Clarke, 2006) and considered the possible generative mechanisms that might underpin student teachers' experiences (Blaikie, 1993). The coding served as an initial mechanism for familiarisation with the data and beginning to collate similar experiences, feelings and ideas. The data were initially open coded using Nvivo (QSR International, 2015) to allow us to begin making sense of the ideas contained within the students' narratives. These codes were then grouped into categories and broader themes (Braun \& Clarke, 2006). For example, the open code 'knowledge for knowledge's sake' became part of the category relating to 'the love of labels' which itself became part of the broader theme relating to 'positive feelings' under the umbrella theme of 'affect'. While the interviews covered a wide range of topics (e.g. how 
grammar is taught in schools, assessment of grammar, etc.), only those themes relating to student teachers' affective responses are discussed here.

After the initial coding of the data, we moved away from the rigidity of the codes to engage more freely with the data, making connections between the students' accounts, our own emerging ideas and a range of theoretical perspectives. While the initial coding served as a clearing ground, enabling us to make the wealth of data manageable and allow initial senses (and sensations) around the data to emerge, the second stage allowed us to move away from the relatively banal process of categorisation to a more productive analytical process of connecting data, researcher and theory (Maclure, 2013a). Through this ongoing cyclical process of reading, thinking and returning to the data, the coding structure was reshaped (e.g. by categorising affective responses into epistemic versus achievement emotions) to allow a reading of the data through related ideas from affect theory and cognitive science (Jackson and Mazzei, 2013). A coda reflecting on how the methodology itself connected with our findings around affective knowledge is included in the online supplementary materials.

\section{Theoretical perspectives}

The ideas emerging from the analysis were informed by affect theory, particularly as developed by Massumi (2002) following Deleuze and Guattari (1988). Within this framework, affects are considered to be relational, impersonal, pre-conscious intensities that are felt in the body, but can never be fully captured in language. While our students attempted to put words to their affective experiences of learning grammar, the emotions which they describe are considered to be a secondary consequence of the intensities that were felt both by them and us during the sessions and follow-up interviews. Our analysis brings together work in affect theory with recent interest in cognitive science in the role of 'epistemic 
emotions' in learning processes. Our work also draws upon the work of Anderson (2009) who characterises affective atmospheres as 'singular affective qualities that emanate from but exceed the assembling of bodies' (p. 80) and the related work of Dufrenne (1973) who highlights the affective qualities of aesthetic objects. Within the analysis that follows, we explore student teachers' accounts of the feelings they experienced when acquiring new knowledge about grammar and their ideas about the underpinning intensities that seemed to be created as they interacted with the nature of the (academic) subject. We consider the affective atmospheres that were felt within the sessions, and how these might have emanated from the 'ensemble of elements that make up the aesthetic object' (Anderson, 2009: 79) - in this case, the structure of one's native language.

\section{Findings}

At the beginning of the grammar course, students frequently reported feelings of fear and anxiety towards grammar, describing it as both scary and difficult. For example, one student teacher describes grammar-induced panic amongst her classmates as follows:

$$
\begin{aligned}
& \text { All of a sudden you go, like say we're gonna look at subordinate clauses, then they'll } \\
& \text { be like 'Oh my god! I don't have a clue. I can't do this and I can never do this and I } \\
& \text { just want to die. }
\end{aligned}
$$

By the end of the sessions, however, all but one of the student teachers interviewed reported positive emotions associated with learning grammar. There was a tangible buzz within our sessions, which fluctuated between apparent fear, panic, joy and giddiness. As the students progressed, there were more of the highs and less of the lows. While these rolling affects could (and probably can to some extent) be attributed to factors other than the nature of the subject (e.g. dynamics of the group, the pedagogical strategies used - see Bell and Ainsworth, 2019), what was striking to us was the dynamic affective atmosphere - 'never finished, static 
or at rest' - (Anderson, 2009, p. 79), which felt more powerful than in other sessions where we taught different subjects (in the case of the lead author) to many of the same student teachers. The fact that students had strong affective responses to grammar learning could, of course, be simply attributed to the fact that grammar was a very unfamiliar subject to the vast majority of our students. We will argue, based on the findings that follow, that the unfamiliarity of the subject did indeed play an important role in the students' affective responses. However, the newness of the subject seemed to constitute more than a superficial 'novelty factor'; rather, the students reported being transformed by the acquisition of a new linguistic lens.

While space does not allow a detailed account of the full range of affective responses observed, we will focus predominantly on the waves of positive affect, which seemed to dominate as the students became more familiar and confident with grammar. These positive affective responses are of particular interest for two reasons: firstly, as discussed above, the current discourse around grammar is predominantly negative and little has been written about the potential for positive affective responses to grammar learning; secondly, many of the student teachers' comments around positive responses to learning grammar seem to relate to epistemic emotions (rather than achievement emotions), which until recently have been overlooked as a key part of the learning process. Our students' positive responses to grammar seemed to go beyond the achievement emotions that we would expect to observe when students master a subject that they initially found difficult. Although students did sometimes talk about 'getting a kick out of' getting things right, the presence of epistemic emotions was much more prominent in the data in terms of both the frequency and intensity of students' responses. By exploring in detail student teachers' positive responses to grammar, we hope to add both to the debate around the value of grammar in the curriculum and to the growing body of work around the educational implications of epistemic emotions. 
It is important to note, however, that we are not claiming that all responses to learning grammar are positive. Within Table S1 (online supplementary materials) we have included an overview of the key themes relating to affect which emerged from our data, along with an indication of how many students shared views in line with each one. It is clear from this overview that students did indeed experience a number of negative responses in relation to grammar. What was striking, however, was that the negative responses preceded the positive responses, which rewarded students as long as they persevered beyond the initial struggle.

We acknowledge that the positive affective responses experienced here may not be experienced by all learners. As with other research designs involving self-selecting samples, there is the possibility that the findings gathered from student teachers who attended the optional sessions and also signed up for the interviews, might be very different than those we might have collected from students who did not. It is possible that student teachers who have identified themselves as having a particular subject knowledge deficit might be particularly susceptible to moments of intensity as they experience effective grammar teaching (possibly for the first time). We do not therefore make the claim that grammar is a source of wonder for learners but that it can be.

\section{For the love of labels}

Three student teachers described enjoying learning 'knowledge for knowledge's sake', linked to a seemingly pervasive drive to know the names of things. In one of the interviews, the students became very animated when discussing their affinity to obscure vocabulary, citing their love of quiz shows as evidence of their thirst for general knowledge. One student retold with excitement an anecdote, which centred around her teaching a young child about the word 'aglet' (the casing that goes around the end of a shoelace). The student spoke of the child's excitement at learning this exotic word; he reportedly couldn't wait to get home and 
ask for some new aglets for his laces. The point that the student was making is that there is something inherently exciting about learning labels for things, and that this is part of the joy that comes from acquiring metalinguistic terminology. While this particular student teacher suggested that her love of labels was peculiar - 'I'm a bit of nerd with things like that [...] this is just me', this giddiness around lexical knowledge seemed to be widespread amongst our students. As the student spoke, there was vigorous agreement from the rest of the group and students delighted in joining in with a song about aglets that they had learnt from a cartoon. In another interview, a different student raised the connection between grammar learning and the seemingly natural desire to acquire general knowledge for the sake of it, again relating their love of trivia to their favourite quiz show. These discussions around an apparently common desire to develop linguistic knowledge provide an interesting counternarrative to the predominantly negative discourse around the recent emergence of grammar terminology within English teaching (Watson, 2012). While critics have argued that a strong emphasis on technical terminology within schools is inappropriate and can be demotivating (Rosen, 2018; Wyse \& Torgerson, 2017), some of our students found these obscure words to be part of the subject's allure.

The acquisition of new words has a clear communicative function; it also seems to be tied up in the cognitive architecture of our minds. Categorisation of objects (whether concrete or abstract) is widely accepted as a playing a crucial role in the way that we process our environment, helping us to deal with the most salient aspects of our sensory milieu quickly and efficiently (e.g. Cohen and Lefebvre, 2005). Brun et al., (2008) have argued that epistemic emotions serve the evolutionary purpose of motivating such acquisition of knowledge. Yet, Crystal argues that our logophilic tendencies go beyond the pragmatic advantages afforded by language. Crystal, who has passionately championed linguistic knowledge as a source of fascination, emphasises the joy that comes from the playfulness and 
generativity of language. In an interview for the British Council he proposed that alongside the need for intelligibility and identity, 'there is a third force of language that is even more important than that, and that is the need to play with language, to enjoy language for its entertainment value' (Crystal, 2013, 00:04:15). The capacity to take pleasure from learning about and playing with language starts early. It is widely recognised that young children delight in the sound and feel of new words, taking pleasure from disrupting linguistic rules and producing a-grammatical refrains (Maclure, 2016). When used playfully, language does not serve a communicative function but 'mobilizes sensations and affects' (p. 178).

Within the broader literature around affective aspects of learning, Schinkel has suggested that the acquisition of facts to be tested, including the categorisation and naming of things 'may be antithetical to the experience of wonder' (2017, p. 539). Drawing on the work of poet Rainer Maria Rilke (1948, cited in Schinkel, 2017), Schinkel suggests that 'things stop singing when they are 'touched' by being named' (p. 539). On the contrary, our findings seem to suggest that linguistic labels animate their referents (as well as their observers), transforming objects which may otherwise have gone unnoticed into 'glittering linguistic subjects' (Crystal interviewed by Marques, 2017, p. 1084). The potential of names to bring to life underlying entities resonates with Massumi's notion that the naming and subsequent making conscious of self-perception allows a background 'sense of aliveness' to come to the fore (2002, p.36). We might speculate that the naming of parts within the structure of one's own language might also allow the vitality of language to be consciously experienced.

\section{Being let into a secret - the mystery of arcane knowledge}

For some student teachers, the grammar terminology, once mastered, seemed to bring a sense of having been let into a secret, leading to feelings of relief and satisfaction: 
It is kind of gratifying when you finally get it and you think, ah! I knew what that was all along, but I didn't know what it's called!

It is interesting that this student teacher (and others) framed the arcane nature of grammar terminology as a source of pleasure, given that this very characteristic is often perceived as a reason for not teaching grammar. For example, in the fierce debate surrounding the appearance of the term 'fronted adverbial' within the National Curriculum in England, author A. L. Kennedy argues that grammar terminology is obscure, unnecessary and unhelpful to children (2016). Kennedy laments the emphasis on 'naming of parts' and makes an impassioned argument for meaningful human communication to be foregrounded. We would agree wholeheartedly with Kennedy's points about the need to empower learners to be confident, authentic communicators; however, we would argue that the use of labels has the potential to be empowering for learners, rather than (as Kennedy argues) 'making them feel defeated by the operations of their own words' (Kennedy, 2016, 00:07:50).

One way in which terminology seemed to be empowering for our students was as a placeholder for previously tacit knowledge. Students often spoke of 'lightbulb moments' like the one above - where the grammar terms provided an anchor for their longstanding procedural knowledge of grammar (their non-conscious knowledge of how to use grammatical structures in everyday communication), allowing it to rise into the realm of conscious awareness. For example, one student teacher explained, 'So it's kind of like. "Oh! Actually, well we do know that. We just didn't know, like the correct word to describe it'. The same student described with excitement how the declarative label 'subject' had led her to become much more conscious of the structures underpinning her everyday language use:

This morning I was talking to my son and I was like, "Go!" And I was like "Oh! You go" and then I was thinking that was one of the things we'd spoke about in one of the 
other sessions. So it's like, there's actually a word missing from that sentence (the subject).

The affective atmospheres that seemed to accompany these moments seemed to resonate with Massumi's (2002) notion of affect as the 'interface between implicate and explicate order' ( $\mathrm{p}$. 37). The currents of joy and wonder felt within (and beyond) the classroom seemed to arise as students' implicit knowledge of language structure became explicit. This echoes Crystal's (2017) observation that people 'are fascinated when they realize just what it is they have acquired as a result of learning the grammar of their language - that they have mastered rules they never knew they knew' (p. 160). Interestingly, the theme of 'being let into a secret' and its associated affects resonates with the etymological evolution from the word 'grammar' to 'glamour'. This gradual shift in meaning through the ages included definitions of 'secret knowledge', 'enchantment', 'charm' and physical allure' (Crystal, 2017, xvi).

While the notion that labels might provide an anchor for existing implicit knowledge does not appear to have received much attention within the area of grammar learning, this is an active field of research within the area of early reading. While the nature of phonological development remains contested, recent empirical work (Ainsworth et al., 2019) suggests that while phonemes begin to emerge naturally within children's cognitive representations through oral language experience, they only become 'sharpened' into completely phonemic representations, once children have learnt about letters (Werker \& Curtin, 2005). The idea that explicit labels can bring concepts into focus at a cognitive level is further supported by computational simulations modelling the relationship between language and thought (Lupyan, 2012). Within the area of early reading, this sharpening up of the child's phonological representations, facilitated by the provision of explicit phonemic labels (in the form of graphemes), represents an important stage of a child's phonological development. We might also wonder whether the provision of explicit labels for grammatical structures 
(e.g. adverbial, subject, object) might lead to a similar reconfiguring of children's syntactic representations, possibly with developmental advantages.

An example which the first author (who also had limited knowledge of grammar terminology prior to the project) contributed to the discussion during one of the interviews resonates with the idea of declarative labels reshaping syntactic representations:

\section{I know what you mean because I often say "Get me them pens" or "Get me them cakes", you know like when I'm at home. And now I always think, "Oh, that's interesting! Because what I'm doing is swapping a determiner for a pronoun”.}

The fact that these kinds of reflections occur 'online' during everyday speech away from the sessions suggests (albeit very tentatively) that the new labels acquired are affecting the selfmonitoring that goes on during speech. It is as though the utterance "Get me them pens", no longer 'sounds right' when the brain carries out its usual process of producing speech and comparing it to what is expected as contained within a multilevel efference copy - a signal which allows the comparison of produced and desired action and may contain information about the 'meaning, grammar, and sound involved in language' (Pickering and Clark, 2014, p.453). While these ideas are purely speculative, the simulation and empirical testing of the potential impact of grammar terminology on learners' representations of language at a cognitive level is a potentially fruitful area for future research. For the moment, we merely note that the merits of explicit engagement with terminology are worthy of further consideration.

\section{Grammar as a linguistic lens}

A side effect of the transformation of previously tacit knowledge into a conscious awareness of grammar seemed to be a new lens through which to view both students' own language use and that of others. Some student teachers talked about the practical benefits of increasing 
their grammar knowledge in terms of its impact on their academic writing. This perceived advantage seemed to be mediated by a level of metacognition that had not been there before. For example, one student described how their explicit knowledge of grammar made them notice limitations in their own writing style while proofreading an assignment:

I was using adverbials pretty much to start every single sentence. You know like sort of 'however', 'therefore'. But then I was like, you don't always have to do that. [...] I didn't even know what an adverbial was six weeks ago. So then I was like, actually I can move that around.

However, the impact of this newfound knowledge seemed to provide them with much more than the instrumental capacity to improve their writing. Students seemed to be newly sensitised to elements of their native language, reporting that an awareness of grammar lurked at the fore even when they were relaxing:

I'll be like reading a magazine and I'll be like ooh, there's the subject, there's the object!'

I'll be all weird like, 'Ooh! But should that have a comma, because that's a ...whatever.'

There was a sense that once you developed knowledge about grammar, there was no going back. For some students, their experiences of language now appeared to be augmented by a level of metacognition which was previously absent, and seemed entirely welcome. The idea of students appearing to be permanently changed by their grammar learning connects with Frith's work around learning to read. Frith considers the acquisition of an orthography as akin to being infected by a virus, after which, 'language is never the same again' (1998, p. 1011). Our data makes us wonder if a similar conceptual reconfiguration occurs when learning explicit grammar knowledge, as explored above. 
Our students were so excited about the new linguistic lens they had acquired that they were keen to let others in on the secret. Frequent reports across a number of interviews were made about students 'spreading the word', taking grammar outside of the classroom seemingly to anyone who would listen. One aspect of grammar knowledge which the students seemed to find particularly exciting was the absence of a future tense in English ${ }^{1}$ :

Every time I met somebody, I just had to tell them all about it. I was like, 'Did you know that there is no future tense in the English language?!' And they were like, 'What do you mean?', And then I was totally explaining it [...] I was like, 'It's amazing, isn't it?!' [...] It's fascinating, because it's something that's so...it's one of the first natural things you do in the first year... and then when you suddenly...it just...when you learn something, about a language that you have spoke for twenty years of your life, and you realise that there's no future tense in your language, it just completely blows your mind. You're like, 'What?!'

The excitement with which this student teacher (and many others) talked about grammar was both striking and contagious. The students' compulsion to share their newfound discoveries seemed to be driven by transpersonal affects (Anderson, 2009). The affects seemed to arise from uncovering a structure which had been until then hidden in plain sight. The students were propelled into a new state of excitement and were infused with a potentiality which compelled them to 'spread the word' (at home, amongst their classmates and with their friends in the pub). They were also motivated to come back for more, bringing with them to future sessions a sense of expectant intensity. Students seemed keen to create further pockets of intensity in between the sessions, e.g. by emailing grammar jokes to us; one student

\footnotetext{
${ }^{1}$ Many linguists claim that there is no future tense in English because there is no special way to change verbs into a form which expresses future time. Instead, to talk about the future in English, we use auxiliary verbs (e.g. I will go).
} 
teacher even wrote us a poem about her experiences of learning grammar. The excitement experienced by our students might be explained at least in part by the wonder that comes with the development of new ways of seeing and categorizing the world - as the familiar (in this case students' procedural knowledge) becomes defamiliarised (Schinkel, 2017), reshaped into a set of interconnected abstract metalinguistic categories.

\section{'Honestly, it was really, really good!'}

A common theme throughout the data was students' surprise at enjoying the grammar sessions. In the following extract, one student teacher talks through an image that he created when asked to illustrate his feelings towards grammar:

It's the first time I've ever experienced grammar in a fun way. I think that's probably one of the reasons why we and the children see it as so... boring would be one of the words-or difficult. You know, that's the first time I've ever experienced a fun interactive grammar session. And it's really changed my perception of it. Even my picture, half of it's all sunshine and rainbows and fun, because like before it would have all just been like atomic bombs and fire and burning. Because you know that would have been my perception of grammar.

The quick transition from 'atomic bombs and fire and burning' to 'sunshine and rainbows and fun' described above and the fluctuating affects of fear and joy that we sensed more generally within the sessions might relate to the 'close relationship between wonder and fear' noted by Schinkel (2017, p. 541). As the complexity of grammar was revealed to our students, their responses seemed to reflect the multiplicity of wonder, which 'ranges from the delightful to the terrible and the horrible '(ibid, p. 541). Those moments when students were deeply troubled by grammar may not have hindered students' capacity to take pleasure from learning grammar, but rather may have been an important antecedent to enjoyment. In other words, 
the fact that grammar knowledge is complex and mysterious is something that has the potential to act in its favour, rather than being merely a deterrent. The fact that grammar seemed able to evoke both fear and joy agrees with the notion of affect as a preconscious intensity, which has yet to settle into a tangible emotion (Deleuze \& Guattari, 1988; Massumi, 2002). Our findings are in agreement with the idea of pockets of intensity emanating from the affective charge of the subject (grammar), being captured by emotions of different valences, depending on the particular circumstances of the learning event.

Once students realised that grammar had the potential to bring pleasure rather than (or at least as well as) fear, they were keen to change the minds of others. One student teacher described her attempt to round up new recruits for the sessions: 'We were like, "Are you coming? Honestly, it was really, really good!"' It is clear from the wording that this student did not expect her colleagues to believe that grammar learning could be an enjoyable enterprise. We hope that this paper provides an interesting starting point to shift the discourse around grammar away from 'the trail of fear left behind by old-fashioned grammarians and their pedantic followers' (Brown, 2014: online) to the possibility of grammar as a source of pleasure, wonder and intensity.

\section{Discussion}

\section{A case for affective knowledge}

Affect relates to motivation but not just in terms of teachers artificially creating affect through psychopedagogies to maximise student performance. Rather affective atmospheres can emanate from the subject itself, inspiring students to become active (and excited) agents rather than 'malleable, correctable and optimizable' objects (Williamson, 2016, p. 414). Psychological accounts of affect and learning tend to focus on the conditions required to put learners into states of arousal conducive to efficient processing of information. Within our 
study, however, the subject matter when placed in interaction with the learner seemed to create affects of its own, which did much more than this. Rather than simply making students more efficient and susceptible to learning, the high levels of affect seemed to generate both 'towardness' and 'awayness' (Ahmed, 2014, p.8). While many of our student teachers felt an initial aversion towards grammar, as they became open to its intrinsic wonder, they became drawn towards it. This sense of wonder also propelled them forward as agents in their own (and others') learning, wanting to come back for more to experience further intensity and to share their excitement with others.

These propulsive affects seemed to emerge primarily from the subject. Within Dufrenne's work (1973) on the phenomenology of the aesthetic experience, it is suggested that aesthetic objects possess affective qualities, which elicit a feeling or emotion in someone coming into contact with the object. While Dufrenne focuses on the affective quality of 'self-enclosed aesthetic works' (Anderson, 2009, p. 79) -e.g. sculpture, music, architecture, Anderson argues that other 'objects' might also be said to be atmospheric. We would argue that grammar (and indeed other academic subjects) might act as such an object, which can 'be animated by singular affective qualities' (p. 79).

It is important to note that while we have suggested that intensities emanated from particular characteristics of grammar, the affective atmospheres did not reside solely within the subject. Anderson argues for the indeterminacy of atmospheres as follows:

On the one hand, atmospheres require completion by the subjects that 'apprehend' them. They belong to the perceiving subject. On the other hand, atmospheres 'emanate' from the ensemble of elements that make up the aesthetic object. They belong to the aesthetic object.'(p. 79) 
Thus, we might consider the affective responses that we observed to be relational intensities that reside between grammar and the learner rather than being fixed within one or the other.

The centrality of the subject itself in generating affective atmospheres leads us to ask whether sufficient attention is given to the role of affective knowledge (versus affective pedagogy) within education. We are of course not suggesting that pedagogy is irrelevant, nor that it is a bad idea to plan lessons which are interactive and engaging; rather we suggest that consideration of the intrinsic value and capacity for wonder of a particular subject might provide a more authentic engagement, where students feel empowered to invest in their own learning and are compelled to share their discoveries with others. Our findings suggest that it is important for us to explore the potentiality of the subject to generate high levels of affect, rather than focussing on pedagogical techniques which aim to whip up arousal out of nowhere.

\section{Affective knowledge across the curriculum and over time}

Within this paper we have used grammar as a test case for exploring the role of epistemic emotions in the learning process. We might also ask whether other subjects have the potential to generate affective atmospheres. When exploring this question, we need to consider the extent to which the aesthetic qualities of grammar (as argued tentatively here) overlap with those of other academic subjects. While space does not permit any detailed comparisons to be made here, as an example, one might speculate that 'a love of labels' could also underpin positive epistemic responses to the naming of concepts in science, e.g. relating to bodily functions which are also 'hidden in plain sight'. This exploratory study motivates investigation of the different types of knowledge and ways of knowing inherent to other academic subjects and the role of epistemic emotions within their acquisition. 
As well as considering the transferability of our findings to other subjects, it is also important to question the relevance of these findings to learners of different ages with different levels of prior knowledge. There are two important issues to consider here. Firstly, our study draws upon data from a sample of student teachers who are in a very particular position. They are under pressure to develop sufficient subject knowledge to be able to teach grammar to primary school children, despite (in most cases) having never been taught it themselves. We might wonder, therefore, whether the strong affects reported here might be a temporary artefact of this very specific situation. The question that follows is whether or not grammar will continue to be as affectively charged for those school children who are introduced to it from the age of five. This is currently an open question; however, we find the specificity with which our students talked about their affective responses to particular characteristics of grammar knowledge compelling.

Secondly, we might ask whether we would expect children and adults to experience similar epistemic responses to grammar given developmental differences in metacognition and abstract thinking. The extent to which epistemic emotions are inherently metacognitive continues to be debated; however, Carruthers (2017) argues that while epistemic emotions often accompany metacognitive awareness, the epistemic emotions themselves are first order phenomena. If Carruthers' (2017) thesis holds true, there is nothing to preclude children experiencing similar epistemic emotions to adults, although we might expect younger children to be much less able to reflect on and articulate these emotions. Again, this represents an interesting avenue for future research.

\section{A case for wonder}

We agree with Aarts' claim (2018: online) that grammar 'enriches your life' or at least has the potential to. Explicit grammar knowledge seemed to bestow our students with a new layer 
of metacognition, which allowed them to analyse their everyday language use, not just for instrumental purposes, such as improving their writing, but also just for the sake of it, as they enjoyed their new linguistic lens. We observed a strong sense of wonder within the classes and interviews, which seemed to arise from the unveiling of previously hidden knowledge. As described by Schinkel, 'Wonder [...] does not seek new ground but changes the ground under one's feet' (2017, p. 543); we might therefore expect wonder to be evoked as the structure of one's own language is brought into relief. Wonder seems to be an especially powerful manifestation of affect: scholars have noted that wonder engages both body and mind (Daston \& Park, 2001; Maclure, 2013b), animates further thought and can be deeply motivating (Opdal, 2001). It has also been suggested that wonder helps us to admire everyday things, be more open to the world around us (Schinkel, 2017) and might protect us from thoughtlessness (Di Paolantonio, 2018). Given the potentiality of wonder observed here and postulated across numerous philosophical works, an interesting avenue for future work would be an exploration of the role of wonder within other subject disciplines.

We might also ask what kinds of environment might be conducive to wonder, allowing the subject itself the space to do the enticing. One particular obstacle to wonder (e.g. Higgins, 2011) which might be particularly important for the cultivation (or oblivion) of wonder within schools is the drive towards instrumental learning. Wonder may be experienced when acquiring new knowledge, seeing something familiar in a new light (Schinkel, 2017), or in the words of Massumi (2002, p. 134) 'thinking-feeling' something new. Yet, wonder need not be related to the acquisition of knowledge for practical purposes (Di Paolantonio, 2018). Indeed Massumi (2002) describes affect, which he relates to wonder, as having a powerful uselessness which cannot be recruited to instrumentalism nor representation. When we experience wonder at a particular object, we do so not because we want to use knowledge of that object for any particular purpose, but because it has touched us in some way. 
Furthermore, Schmitt and Lahroodi (2008) argue that the decline in curiosity (an epistemic emotion closely related to wonder) that seems to come with age might be due at least in part to the rise in practical concerns that we acquire as we mature. This tension between wonder and curiosity on the one hand and instrumental concerns on the other is especially salient within contemporary school contexts. The focus of much learning within schools is on acquiring knowledge and skills to fulfil some well-defined purpose, with limited space provided for the 'appreciation of things for their own sake' (Schinkel, 2017, p. 550).

Returning to the example of grammar, while the aim to help students develop 'conscious control and choice' (Department for Education, 2013a, p. 64) within their writing is clearly a worthy one, the sole emphasis placed on grammar as a tool rather than as a wonder of nature might limit students' capacity to admire its beauty and sense its affective liveliness. Similar concerns have been aired in relation to other aspects of the English curriculum. For example, the desire to promote reading for pleasure is in tension with policies which 'focus on literacy skills at the expense of meaningful and empowering encounters with texts' (Burnett and Merchant, 2018, p. 62). Burnett and Merchant (2018) highlight the potential of broader literacy practices to affect much more than students' technical skills, generating 'enchantment' (p. 64) which they associate with Maclure's interpretation of wonder as a 'liminal condition, suspended in a threshold between knowing and unknowing' (2013b, p. 228).

These tensions reflect the relative value which we assign to instrumental versus affective learning. We would argue that while our contemporary classrooms tend to value the acquisition of useful knowledge above all else, the sense of excitement and possibility that comes with wonder has the potential to drive a sustained authentic engagement which does not naturally arise from the sober learning experiences which tend to be generated by a preoccupation with instrumental outcomes. If we find ways to open up the wonder of subjects 
to students, we can create 'cognitive passions' (Daston and Park, 2001), which invoke both thinking and feeling. Rather than focusing mainly on achievement emotions (i.e. the sense of reward that comes with completing a task) as contemporary education systems tend to do, we would argue that greater emphasis should be placed on fostering epistemic emotions, captured through the affective characteristics of particular subjects.

\section{Data Availability}

Research data are not shared.

\section{Ethical Guidelines}

Ethical approval for this study was granted by the Faculty of Education Ethics Committee at the authors' institution.

\section{Conflict of Interest}

There is no conflict of interest associated with this study.

\section{References}

Aarts, B. (2018). Long read: do teachers really hate teaching grammar? Times Educational Supplement. Available online at: https://www.tes.com/news/long-read-do-teachers-reallyhate-teaching-grammar (accessed 24 June 2018).

Ahmed, S. (2014). The Cultural Politics of Emotion (2 ${ }^{\text {nd }}$ edn) (Edinburgh, Edinburgh University Press).

Ainsworth, S. L., Welbourne, S., Woollams, A., \& Hesketh, A. (2019). Contrasting Explicit With Implicit Measures of Children's Representations: The Case of Segmental Phonology, Language Learning, 69(2), 323-365. https://doi.org/10.1111/lang.12334 
Anderson, B. (2009). Affective atmospheres, Emotion, Space and Society, 2(2), 77-81. https://doi.org/10.1016/j.emospa.2009.08.005

Bell, H. (2016). Teacher knowledge and beliefs about grammar: A case study of an English primary school, English in Education, 50(2), pp.148-163.

Bell, H. \& Ainsworth, S. L. (2019). Hard to know or hard to say? Developing Explicit Grammar Knowledge among Primary Student Teachers. In: Voices and Practices in Applied Linguistics: Diversifying a Discipline. White Rose University Press.

Blaikie, N. (1993). Approaches to Social Enquiry (Cambridge, Polity Press).

Braun, V. \& Clarke, V. (2006). Using thematic analysis in psychology, Qualitative Research in Psychology, 3(2), 77-101. https://doi.org/10.1191/1478088706qp063oa

Brown, J. (2014). Why grammar isn't cool - and why that may be about to change. The Guardian. Available online at: https://www.theguardian.com/media/mind-yourlanguage/2014/mar/21/mind-your-language-cool-grammar (accessed 28 August 2019).

Brun, G., Doğuoğlu, U. \& Kuenzle, D. (2008). Epistemology and emotions (Aldershot, Ashgate).

Burnett, C., \& Merchant, G. (2018). Affective encounters: enchantment and the possibility of reading for pleasure, Literacy, 52(2), 62-69. https://doi:10.1111/lit.12144

Carruthers. P. (2017). Are epistemic emotions metacognitive? Philosophical Psychology, 30(1-2), 58-78, https://doi:10.1080/09515089.2016.1262536

Clough, P. T. (2007). The Affective Turn: Theorizing the Social (Durham, Duke University Press). 
Cohen and Lefebvre, (2005). Bridging the Category Divide, in: H. Cohen \& C. L)efebvre (Eds.) Handbook of Categorization in Cognitive Science (2 ${ }^{\text {nd }}$ Ed.). (London, Elsevier). https://doi.org/10.1016/B978-0-08-101107-2.00001-4

Crystal, D. (2013). Interviewed by Tony O’Brien for British Council Serbia, 9 November. Available at: https://www.youtube.com/watch?v=SqkIv79KBTw (accessed: 10 October 2018).

Crystal, D. (2017). Making Sense: The Glamorous Story of English Grammar (London, Profile Books).

Deleuze, G. \& Guattari, F. (1988). A Thousand plateaus: capitalism and schizophrenia (London, Athlone).

Department for Education (2013a). English programmes of study: key stages 1 and 2. National curriculum in England. Available online at: https://assets.publishing.service.gov.uk/government/uploads/system/uploads/attachment data /file/335186/PRIMARY_national_curriculum___English_220714.pdf (accessed 11 February 2019).

Di Paolantonio, M. (2018). Wonder, Guarding Against Thoughtlessness in Education, Studies in philosophy and education, 1-16. https://doi.org/10.1007/s11217-018-9626-3

Dufrenne, M. (1973). The Phenomenology of Aesthetic Experience (Evanston, North Western University Press).

Frith, U. (1998). Literally changing the brain, Brain, 121(6), 1011-1012. https://doi.org/10.1093/brain/121.6.1011.

Higgins, C. (2011). The Possibility of Public Education in an Instrumentalist Age, Educational Theory, 61(4), 451-466. https://doi.org/10.1111/j.1741-5446.2011.00414.x 
House of Commons Education Committee (2017). Primary assessment. Eleventh Report of Session 2016-17. Report, together with formal minutes relating to the report (London, House of Commons).

Jackson, A. Y. \& Mazzei, L. A. (2013). Plugging One Text Into Another: Thinking With Theory in Qualitative Research, Qualitative Inquiry, 19(4), 261-271. https://doi.org/10.1177/1077800412471510

Kennedy, A. L. (2016). A Point of View: the power of language. For The BBC. Available at: https://www.bbc.co.uk/sounds/play/b07glx87 (accessed on $22^{\text {nd }}$ June 2018).

Love, K., Macken-Horarik, M. \& Horarik, S. (2015). Language knowledge and its application: A snapshot of Australian teachers' views. Language knowledge and its application, Australian Journal of Language and Literacy, 38(3), 171-182.

Lupyan, G., (2012). What do words do? Towards a theory of language augmented thought, in: B. H. Ross (Ed.), The Psychology of Learning and Motivation, Vol. 57 (London: Academic Press). https://doi.org/10.1016/B978-0-12-394293-7.00007-8 MacLure, M. (2013a). Classification or wonder? Coding as an analytic practice in qualitative research, in: R. Coleman \& J. Ringrose (Eds.) Deleuze and Research Methodologies (Edinburgh, University Press) 164-183.

Maclure, M. (2013b). The wonder of data, Cultural Studies - Critical Methodologies, 13(4), 228-232. https://doi.org/10.1177/1532708613487863

MacLure, M. (2016). The Refrain of the A-Grammatical Child: Finding Another Language in/for Qualitative Research, Cultural Studies $\leftrightarrow$ Critical Methodologies, 16(2), 173-182. https://doi.org/10.1177/1532708616639333 
Marques, W. (2017). An overview of the contemporary English language: changes and perspectives - interview with David Crystal. Available online at:

https://docs.google.com/viewerng/viewer?url=http://www.seer.ufu.br/index.php/dominiosdeli nguagem/article/viewFile/37518/20934 (accessed 3 December 2018).

Massumi, B. (2002). Parables for the Virtual (Durham, Duke University Press).

Muis, K. R., Psaradellis, C., Lajoie, S. P., Di Leo, I. \& Chevrier, M. (2015). The role of epistemic emotions in mathematics problem solving, Contemporary Educational Psychology, 42, 172-185. https://doi.org/10.1016/j.cedpsych.2015.06.003

Niccolini, A. D., Dernikos, B., Lesko, N. \& McCall, S. D. (2018). High Passions: Affect and Curriculum Theorizing in the Present, in: C. Hebert, N. Ng-A-Fook \& B. Smith (Eds.), Internationalizing Curriculum Studies (Cham, Palgrave Macmillan), 157-175. https://doi.org/10.1007/978-3-030-01352-3_10

Opdal, P.M. (2001). Curiosity, Wonder and Education Seen as Perspective Development, Studies in Philosophy and Education, 20, 331-344.

https://doi.org/10.1023/A:1011851211125

Pekrun, R. \& Perry, R. P. (2014). Control-value theory of achievement emotions, in: R. Pekrun \& L. Linnenbrink-Garcia (Eds.), Educational psychology handbook series. International handbook of emotions in education (New York, Routledge/Taylor \& Francis Group), 120-141.

Pickering, M. J., \& Clark, A. (2014). Getting ahead: forward models and their place in cognitive architecture, Trends in Cognitive Sciences, 18(9), 451-456.

https://doi.org/10.1016/j.tics.2014.05.006 
QSR International. (2015). NVivo 11 [Computer software]. Available from http://www.qsrinternational.com

Rosen, M. (2018). Terminology wars in grammar. Available online at:

http://michaelrosenblog.blogspot.com/2018/02/terminology-wars-in-grammar.html (accessed $\underline{3 \text { January 2019) }}$

Safford. K. (2016). Teaching Grammar and Testing Grammar in the English Primary School: The Impact on Teachers and their Teaching of the Grammar Element of the Statutory Test in Spelling, Punctuation and Grammar (SPaG), Changing English, 23(1), 3-21. https://doi.org/10.1080/1358684X.2015.1133766

Schinkel, A. (2017). The Educational Importance of Deep Wonder, Journal of Philosophy of Education, 51(2), 538-553. https://doi.org/10.1111/1467-9752.12233

Schmitt, F. F. \& Lahroodi, R. (2008). The Epistemic Value of Curiosity, Educational Theory, 58(2), 125-148. https://doi-org.ezproxy.mmu.ac.uk/10.1111/j.1741-5446.2008.00281.x

Watson, A. M. (2012). Navigating 'the pit of doom': Affective responses to teaching 'grammar', English in Education, 46(1), 22-37. https://doi.org/10.1111/j.1754$\underline{8845.2011 .01113 . x}$

Werker, J. F. \& Curtin, S. (2005). PRIMIR: A Developmental Framework of Infant Speech Processing, Language Learning and Development, 1(2), 197-234. https://doi.org/10.1111/lang.12334

Williamson, B. (2016). Coding the biodigital child: the biopolitics and pedagogic strategies of educational data science, Pedagogy, Culture \& Society, 24(3), 401-416.

https://doi.org/10.1080/14681366.2016.1175499 
Wyse, D. \& Torgerson, C. (2017). Experimental trials and 'what works?' in education: The case of grammar for writing, British Educational Research Journal, 43(6), 1019-1047.

https://doi.org/10.1002/berj.3315

Zembylas, M. (2007). The specters of bodies and affects in the classroom: a rhizo-ethological approach, Pedagogy, Culture \& Society, 15(1), 19-35.

https://doi.org/10.1080/14681360601162030 
Table 1. Details of course characteristics and sampling

\begin{tabular}{|c|c|c|c|}
\hline $\begin{array}{l}\text { Course iteration and characteristic } \\
\text { features }\end{array}$ & $\begin{array}{l}\text { Number of } \\
\text { students } \\
\text { invited }\end{array}$ & $\begin{array}{l}\text { Number of } \\
\text { students } \\
\text { who } \\
\text { attended the } \\
\text { course* }\end{array}$ & $\begin{array}{l}\text { Number of } \\
\text { students who } \\
\text { participated in the } \\
\text { interviews }\end{array}$ \\
\hline $\begin{array}{l}\text { Cohort } 1 \text { November 2016. Year } 2 \\
\text { students on the BA programme: } \\
\text { - } \quad \text { Transmissive approach } \\
\text { - } \quad \text { Order of terms - small to large } \\
\text { linguistic units (word classes, then } \\
\text { phrases, then clause elements, } \\
\text { etc.) } \\
\text { - } \quad 7 \text { sessions } \\
-\quad 35 \text { grammatical terms covered }\end{array}$ & 183 & 50 & $\begin{array}{l}\text { Interview } 1, n=2 \\
\text { (December } 2016 \text { ) } \\
\text { Interview } 2, n=5 \\
\text { (December } 2016 \text { ) } \\
\text { Interview } 3 \mathrm{n}=3 \\
\text { (December } 2016 \text { ) }\end{array}$ \\
\hline $\begin{array}{l}\text { Cohort 2. Year } 3 \text { students on the BA } \\
\text { programme: } \\
\text { - } \quad \text { Mainly transmissive approach } \\
\text { with some investigation } \\
-\quad \text { Same approach to ordering of } \\
\quad \text { terms as cohort } 1 \\
-\quad 5 \text { sessions } \\
-\quad 30 \text { grammatical terms covered }\end{array}$ & 183 & 17 & $\begin{array}{l}\text { Interview 4, } \mathrm{n}=1 \\
\text { (May 2017) } \\
\text { Interview 5, } \mathrm{n}=10 \\
\text { (May 2017) }\end{array}$ \\
\hline 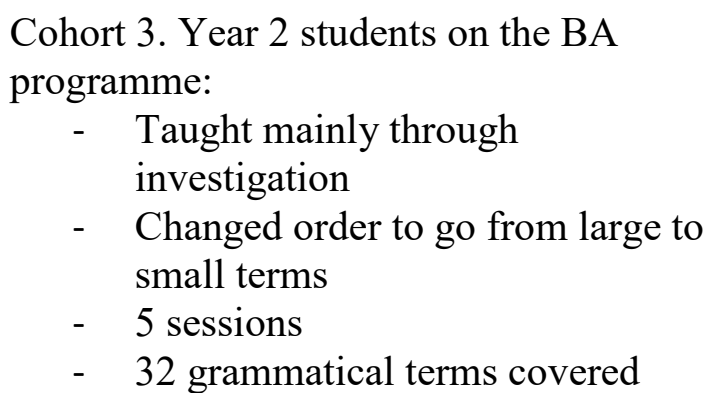 & 206 & 13 & $\begin{array}{l}\text { Interview } 5, \mathrm{n}=5 \\
\text { (December 2017) } \\
\text { Interview 7, } \mathrm{n}=3 \\
\text { (December 2017) }\end{array}$ \\
\hline
\end{tabular}

*Number of students who attended at least one session 


\section{Supplementary Materials}

Table S1. Themes relating to positive and negative affective responses

\begin{tabular}{|c|c|c|c|}
\hline Theme & $\begin{array}{l}\text { Affective } \\
\text { response }\end{array}$ & Participants & Example quote \\
\hline $\begin{array}{l}\text { For the love } \\
\text { of labels }\end{array}$ & $\begin{array}{l}\text { Epistemic - } \\
\text { positive }\end{array}$ & $\begin{array}{ll}\text { Interview } 1 & \text { Student E } \\
\text { Interview } 3 & \text { Student T } \\
\text { Interview } 5 & \text { Student L } \\
\text { Interview } 5 & \text { Student A } \\
\text { Interview } 7 & \text { Student N }\end{array}$ & $\begin{array}{l}\text { A: ...it's called aglet } \\
\text { L: But there was a song on Phineas and Ferb! A. G } \\
\text { A: Yeah, and the dot on top of an I or a J is called a } \\
\text { was just like, I was saying to the child, 'Do you kno } \\
\text { 'Oh, wow! I really wanna go home and say I need s } \\
5 \text { Students A and L) }\end{array}$ \\
\hline
\end{tabular}

Being let into Epistemic - Interview 2 Student B a secret positive

Interview 6 Student $\mathrm{N}$ Interview 6 Student $\mathrm{M}$

Interview 6 Student $\mathrm{C}$ Interview 7 Student A

Grammar as a linguistic lens

Epistemic positive

Spreading the word

Epistemic positive

西

Interview 3 Student $\mathrm{E}$ Interview 5 Student $\mathrm{V}$ Interview 5 Student $\mathrm{R}$ Interview 5 Student $\mathrm{G}$ Interview 6 Student

\section{$\mathrm{M}$}

Changing Epistemic - Interview 1 Student A perceptions positive Interview 4 Student $C$ Interview 6 Student M Interview 6 Student $\mathrm{C}$ Interview 7 Student $P$

Getting it Achievement Interview 1 Student A right - positive Interview 2 Student B Interview 3 Student E Interview 3 Student $T$ Interview 6 Student A Interview 6 Student $\mathrm{C}$ Interview 6 Student $\mathrm{N}$

Cognitive Epistemic - Interview 1 Student A dissonance negative Interview 3 Student $T$ Interview 3 Student $\mathrm{E}$
It just...when you learn something, about a languag of your life, and you realise that there's no future te blows your mind. You're like, "What?!" (Interview

I'll be like reading a magazine and I'll be like ooh, there's... (Interview 5 Student V)

I was in the pub the other day talking about tenses there in English and my friend was like three. And 1 (Interview 5 Student $R$ )

I have really enjoyed it, which does surprise me. (In You get a similar kick out of it when you get the con something right in maths I think. (Interview 1 Stude

It was when I couldn't figure it out or it was like bu way. (Interview 6 Student A) 
Interview 6 Student A

Grammar is complex and can be confusing

Grappling with opaque, technical terminology

Feeling overwhelmed

Fear of exposure

Feeling inferior

Frustration at not understanding
Epistemic negative

Interview 1 Student A Interview 2 Student L Interview 3 Student E Interview 5 Student $\mathrm{R}$ Interview 5 Student L Interview 7 Student A

Epistemic negative

Interview 1 Student N Interview 2 Student $\mathrm{M}$

Interview 5 Student $\mathrm{R}$ Interview 5 Student L Interview 5 Student $\mathrm{E}$ Interview 5 Student $\mathrm{G}$ Interview 5 Student A Interview 6 Student D Interview 6 Student N

Epistemic negative

Achievement Interview 1 Student - negative

A Interview 2 Student B Interview 3 Student $T$ Interview 4 Student $C$ Interview 7 Student $\mathrm{P}$

Achievement - negative

Interview 2 Student B Interview 3 Student $T$ Interview 3 Student $\mathrm{E}$ Interview 6 Student $C$

Achievement - negative
Interview 1 Student $A$ Interview 6 Student A Interview 6 Student A Interview 7 Student P
There's no hard and fast rule, is there? Like, that's it's very straight forward. It is what it is [...] where grey areas that you're a bit like "ooh". (Interview

You say some of those big words to us and you thin sounds complicated. The concept might not be com makes it so hard.

(Interview 5 Student L)

I was pretty scared of it, I think, at the start and kin there is, and the amount of terms that I've heard of (Interview 7 Dec Student P)

I'd be going through things [...] I'd get myself in a correcting me at some points [...] It's horrible. It's wrong and I don't know if they're right. That I've g there's more of them telling me.

(Interview 1 Student A)

I was on placement, I was sort of given these thing threw me. Because I felt a bit like...I felt really stup all this?' and I didn't. (Interview 2 Student B)

If I forget something then I get not confident and th frustrating like you saw. And then I'm back up and 


\section{Coda - wonder in method}

It is interesting to acknowledge the parallels between the affects felt by the students and ourselves as researchers. During both the data collection and analytic processes, we became aware of our own affective responses. Sometimes powerful affects were felt when a particular code seemed to 'hit the spot', fostering coalescence between the assemblage of data, theory and experience. For example, during one of the interviews, the first author exclaimed excitedly, 'I think it's like a virus though isn't it?!' as a connection was sparked between what the student had just said about grammar invading their everyday life (when reading a magazine), the author's own similar experiences ('them pens') and the author's memory of Frith's virus metaphor for the acquisition of alphabetic knowledge (1998). The waves of giddiness and excitement that rippled through the research process seemed to appear at liminal points, as the sense-making process led to our own 'light-bulb' moments. Even as I (first author) write this, I feel 'the wonder of data in the gut' (Maclure, 2013b, p. 229) as I consider the origins of these affects and ask if they emerged from the labelling of codes or from elsewhere. The word 'connections' springs to mind and sparks a visceral response as I sense that it seems to be the process of joining one thing to another rather than the codes themselves that evokes these pockets of intensity. The labels generated through coding, at times, were able to awaken these connections, but only in the context of a bringing together or 'plugging in' (Jackson and Mezzei, 2013) of the researcher's existing schemas, the work of others and the new data collected from and with the participants.

For us the epistemic wonder simultaneously experienced by the students as they grappled with grammar, and ourselves as we tried to make sense of our data, seemed to share a common origin - the transformation of knowledge as the old assimilates with the new. In the case of the students, wonder seemed to arise from declarative knowledge bringing into focus existing procedural knowledge; within the research process, wonder arose from the new assemblage created by the connection of researcher, data and theory (Deleuze and Guattari, 2004; Maclure, 2013a). While this coda, provides only anecdotal evidence of the role that epistemic emotions (in particular wonder) might play in the research process, we suggest that this provides an interesting avenue for future research. 